\title{
DRIP IRRIGATION EFFECT ON SUNFLOWER OIL PRODUCTION IN THE SANDY SOIL.
}

El Awady, M. N. ${ }^{(1)}$; Altellawy, F. M. M. ${ }^{(2)}$; Kishk,Y. F. M. ${ }^{(1)}$; Albagoury,Kh. T. ${ }^{(1)}$ and El Sarraf, A. M. ${ }^{(3)}$

1) Faculty of Agriculture, Ain Shams University. 2) Institute of Environmental Studies and Research, Ain Shams University 3) Agricultural Engineering Research Institute of Irrigation and Drainage - Agricultural Research Center

\begin{abstract}
Effect of using different drip irrigation treatments on the properties' of extracted sunflower oil were investigated. The following resulted for two seasons (2013 and 2014) for the Surface and Sub Surface Drip Irrigation treatments (SDI and SSDI).Two sunflower varieties (Saka 53 and Giza102) were included in the treatments. For: season (2013) and variety Giza102: Ir. Systems, resp.: SDI and SSDI ETo \%, From 50 to 100 yield $\mathrm{kg} / \mathrm{fed}: 512$ to 1055 oil \% 30.4 to $43.4 \%$. Corresponding results prevailed for the subsequent season for the yields and oil ratios by the two irrigation systems tested and sunflower varieties. In conclusion, the irrigation treatments have shown great effects on the oil yield and quality.
\end{abstract}

\section{INTRODUCTION}

Irrigation is the determinant factor in agriculture and water scarcity should be regarded for the maximum benefit in crops. Drip irrigation is one of the most important irrigation methods in the reclaimed lands of Egypt. There is a gap in the production of oil crops. It is necessary to expand the cultivation of these crops. The most important oil plant is probably sunflower. Water in Egypt should be saved to help preserve the environment from pollution of residue fertilizers used in agriculture, which may reach the ground water. 
Under water scarcity, productivity of a crop can be improved significantly through drip irrigation by decreasing the leaching evaporation and surface runoff loses. El-Hendawy et al. (2008) Iterated that subsurface drip irrigation system offers great potential for increasing crop production in arid lands, because it reduces the consumption of the amount of irrigation water that gives way to the expansion of cultivated areas. Crop water models could be important decision-support tools for improved irrigation management. Irrigation interval may be increased the tolerant genotypes grown. Drip irrigation either at $100 \%$ of ETc or $80 \%$ ETc with $100 \%$ of RDF or $80 \%$ of RDF produced significantly higher seed yield, Sinha et al. (2017). Sunflower Helianthus annuus, L. Asteraceae (compostiae) is from the tropic crops and it produces economically in warm areas. Sunflower is characterized by ability to adapt to climate with high and low temperatures. As a result of improvement and the election of the varieties planted sunflower spread from subtropical areas in South America until the cold regions in Russia and Canada.

Sunflower plant is high resistant to drought, fast growing and absorbs water and nutrients efficiently (Gimenez, and Fereres 1986).The sunflower is important oil crop all over the world. Soviet Union, United States, Eastern Europe, Argentina, Southern European countries and South Africa planting it mainly oil crop (Kandil, 2000). Sunflower (Helianthus annuus L.), is an excellent source of heart-healthy unsaturated fats. It has become the second most important oil crop next to soybean in the world (FAO 2011). Sunflower is one of the most important oil crops and due to its high content of 
unsaturated fatty acids and a lack of cholesterol, the oil benefits from a desirable quality (Razi and Assad, 1999). Sunflower is rich of oleic monounsaturated fats, therefore considered as a useful source of dietary fat in preventing heart disease (Allman-farinelli et al., 2005). Sunflower is preferable than the other oil crops such as cotton, rapeseed, and peanut, by the short period in the field, and high productivity of oil. The objective of this research is investigating the effects of water supply on the productivity of sunflower crop and oil properties. As irrigation is known to boost both growth and yield of sunflower.

\section{MATERIALS AND METHODS}

1) The study area and soil: Field experiments were carried out in the private farm near, (Wady Al Molak Ismailia وادى الملاك، اسماعيلية) Egypt, in sandy soil. Area of the experiment was $30 \mathrm{~m}$ x $24 \mathrm{~m}$ divided to 18 furrows of 150 $\mathrm{cm}$ width. Two successive summer seasons of 2013 and 2014 were included two varieties of Sunflower (Saka 53, Giza 102) were used in the experiments. Four irrigation water treatments were included $(0.50,0.60$, 0.80 , and 1.0 of the reference crop evapotranspiration). The drip irrigation system comprised GR dripper liner, 4 liter per hour capacity, diameter 16 $\mathrm{mm}$ with $30 \mathrm{~cm}$ emitters spacing. Surface Drip Irrigation (SDI) was used and the second was Subsurface Drip (SSDI) fixed at $15 \mathrm{~cm}$ depth under soil surface. Drip irrigation systems were set up according to the treatments presented in Fig (1). The soil of the experiment is classified as sandy soil. Soil analyses were made at the laboratory of Soil, Water and 
Environment Res. Institute (S.W.E.R.I) before planting sunflower according to (Jackson, 1978), ( Day, 1965) and (Black, 2000).

Climate data of (ETo) were obtained from local weather station at Ismailia, affiliated of the Central Laboratory for Agricultural Climate (C.L.A.C), Ministry of Agricultural and land Reclamation.
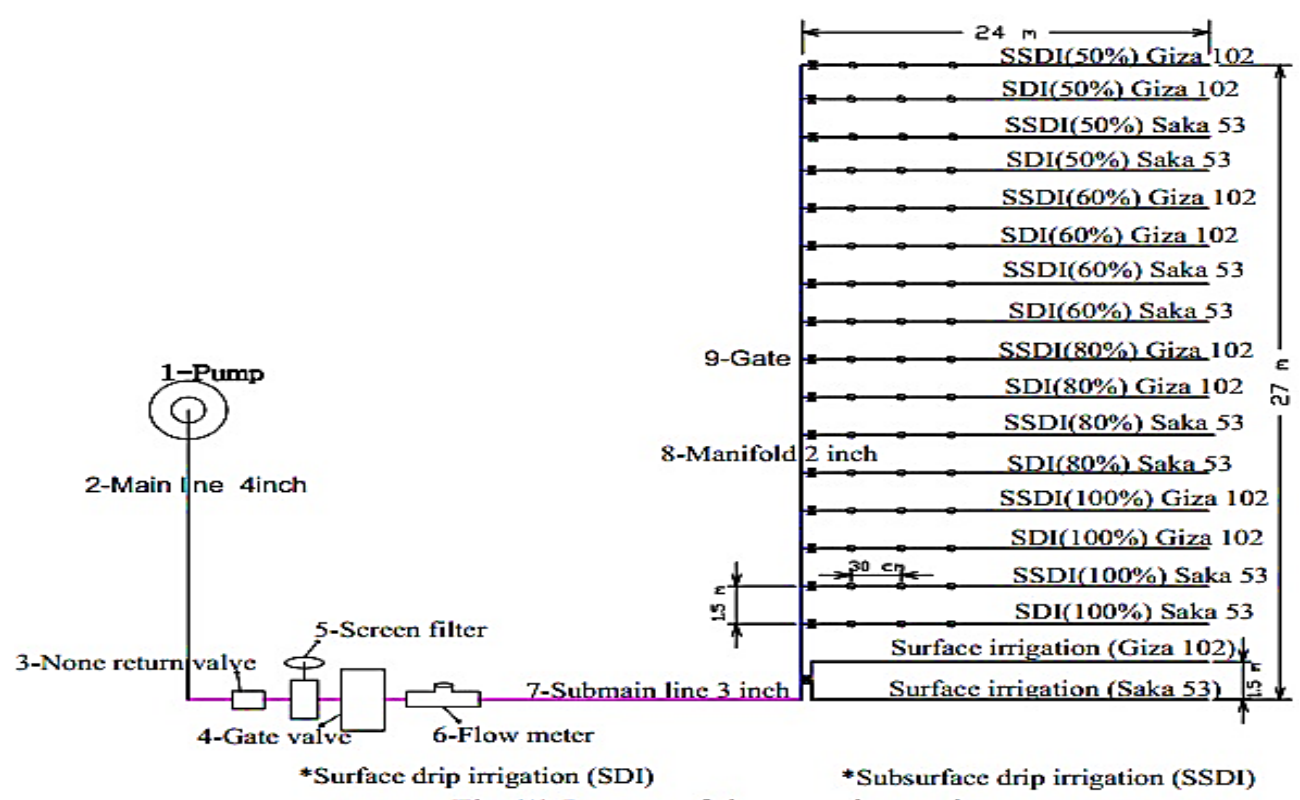

Fig.(1) Layout of the experimental area.

2) Agricultural operations and irrigation water: Two hybrid sunflower seeds (Saka 53 and Giza 102) were obtained from Oil Seeds Crop Dept., Field Crop Res. Inst., Agric. Res. Center, Giza, Egypt. 
Table (1): Crop coefficient for sunflower crop.

\begin{tabular}{|c|c|c|c|c|}
\hline Crop & $\mathbf{K}_{\text {c ini }^{1}}$ & $\mathbf{K}_{\mathbf{c} \text { mid }}$ & $\mathbf{K}_{\mathbf{c} \text { end }}$ & Maxi crop height $(\mathbf{h})(\mathbf{m})$ \\
\hline \hline Oil crops & 0.35 & 1.15 & 0.35 & 2.0 \\
\hline Sunflower & & $1.0-1.15^{9}$ & 0.35 & \\
\hline
\end{tabular}

FAO (2011) http://www.fao.org/nr/water/cropinfo sunflower.html

Table (2): Observed crop coefficient for sunflower crop and diet.

\begin{tabular}{|c|c|c|c|c|c||}
\hline \multirow{2}{*}{ Crop $\mathbf{K}_{\mathbf{c}}$} & $\mathbf{K}_{\mathbf{c} \text { Initial }}$ & $\mathbf{K}_{\mathbf{c} \text { Develop }}$ & $\mathbf{K}_{\mathbf{c} \text { Mid }}$ & $\mathbf{K}_{\mathbf{c}}$ & \multirow{2}{*}{ Total days } \\
\cline { 2 - 5 } & $\mathbf{0 . 3 5}$ & $\mathbf{0 . 7 5}$ & $\mathbf{1 . 1 5}$ & $\mathbf{0 . 3 5}$ & \\
\hline \hline Giza102 & 16 day & 21 day & 25 day & 17 & 79 \\
\hline Saka 53 & 16 day & 30 day & 32 day & 16 & 94 \\
\hline
\end{tabular}

Penman-Monteith equation and Kc, as illustrated in Allen et al.(1998), is presented in the tables (1) and (2) for crop evapotranspiration (ETc), four stages: initial, development, mid, and late. (Saka 53, and Giza 102 varieties). According to Isrealsen and Hansen, (1962)

$$
\mathbf{E T}_{\mathbf{c}}=\mathbf{E T}_{\mathrm{o}} \mathbf{X ~ K c}
$$

\section{[Eq.1]}

Where:

$\mathrm{ET}_{\mathrm{c}}=$ Crop water consumptive use, $\mathrm{mm} / \mathrm{day}$.

$\mathrm{ET}_{0}=$ Reference evapotranspiration, mm/day.

$\mathrm{K}_{\mathrm{c}}=$ crop coefficient.

Emission uniformity $(E U)$ is determined as a function of the relation between the average flow by $25 \%$ of the emitters with the lowest flow and the mean flow emitted by all the control emitters, as Eq. (1) shows (ASAE 1996a):

$$
\mathrm{EU}=\underline{\mathrm{q} 25} \% / \mathrm{q} a x \mathbf{x} 100
$$


Where:

$E U-$ emission uniformity $(\%)$

q25\% - average of $25 \%$ of the lowest values of flow rate $(1 / \mathrm{h})$

$\mathrm{q} a$ - average flow rate $(\mathrm{l} / \mathrm{h})$

Crop coefficients, $\mathrm{K}_{\mathrm{c}}$, and mean maximum plant heights for non-stressed, well-managed crops, in subhumid climates $\left(\mathrm{RH}_{\min } 45 \%, \mathrm{u}_{2} 2 \mathrm{~m} / \mathrm{s}\right)$ are used with the FAO Penman-Monteith ETo. The flow pressure relationship and flow regime of emitters were calculated using Equation 1 (Keller and Karmeli, 1975) (ASAE, 1990).

$$
\mathbf{q}=\mathbf{k} \mathbf{H}^{\mathbf{x}}
$$

" $q$ " is the emitter flowrate, " $\mathrm{k}$ " is emitter discharge coefficient, " $\mathrm{x}$ " is the emitter discharge exponent, which characterizes the flow rgime and " $\mathrm{H}$ " is the entry water pressure (Keller and Karmeli, 1975). Manufacturing variation coefficient (CV m). Has been measured by Equation2 (ASAE, 2002).

$$
\mathrm{Cv}=\mathrm{S} / \mathrm{X}
$$

\section{[Eq.4]}

" $\mathrm{X}$ " is described as the average flow of emitters " $\mathrm{S}$ " is as standard deviation. In point source emitters, if $\mathrm{Cv}$ mean value is less than 0.05 it is assessed as perfect, between 0.05-0.07 is good, 0.07-0.11 is at limit, 0.11-0.15 is very bad and if it is more than 0.15 that is unacceptable (ASAE, 2002). The "S" value given in Equation 2 is given by Equation 3.

$$
\mathbf{S 2}=\left[\sum(\mathbf{X i}-\mathbf{X})^{\mathbf{2}}\right] /(\mathbf{n}-\mathbf{1}),
$$

Where "Xi" is the emitter flow $(1 / \mathrm{h})$ and " $\mathrm{n}$ " is the number of emitters. The statistical uniformity between the emitters is determined by Equation 4 (Bralts and Kesner; 1983). 


$$
\mathrm{Us}=100(1-\mathrm{Vq})=100(1-/ \mathrm{q} / \mathrm{Sq} .) \quad \text { [Eq.6] }
$$

In the equation "Us" defines statistical uniformity (\%), "Vq" describes the overall change in emitter flows, "Sq" is the standard deviation of emitter flows and "q" mean emitter flow rate. Statistical uniformity is evaluated as perfect for $95-100 \%$, good for $85-90 \%$, tolerable for $75-80 \%$, very bad for $65-70 \%$, unacceptable for $60 \%$ and less (ASAE, 1994).

Application uniformity (Eu) expresses the uniformity of emitters.

3) Sunflower oil: Expeller gets oil from sunflower seeds after cleaning of impurities and weighing. Oil is collected from all (18) irrigation experiments after filtering and kept it in dark bottles in the refrigerator for analysis.

4) WUE of seed yield: WUE is an indicator of the effectiveness of use of irrigation water for crop production. WUE of seed yield was calculated from Equation (6):

WUE of seed yield $\left(\frac{\mathrm{kg}}{\mathrm{m}^{3}}\right)=\frac{\text { Total seed yield }(\mathrm{kg} / \mathrm{fed})}{\text { Total applied irrigation water }\left(\mathrm{m}^{3} / \mathrm{fed}\right)}$ [Eq.6]

5) WUE of oil yield: WUE of oil yield is an indicator of effectiveness of irrigation water for crop production, Equation (7):

WUE of oil yield $\left(\mathrm{kg} / \mathrm{m}^{3}\right)=\frac{\text { Total oil yield }(\mathrm{kg} / \mathrm{fed} \text {.) }}{\text { Total applied irrigation water }\left(\mathrm{m}^{3} / \mathrm{fed}\right)}$ [Eq.7]

6) Proximate composition: Samples were analyzed for Moisture, Protein, Ash, Fat according to (A.O.AC., 2000). The Carbohydrates were calculated by differences as Nitrogen free extract (NFE).

7) Oil physico - chemical characteristics: Acid value, peroxide value and Refractive indexes at $20^{\circ} \mathrm{C}$ of oil samples were estimated using procedures AOAC (2000), Anisidine value was determined by the methods described 
by AOCS Official Method Cd 18-90 (AOCS, 1998). Total oxidation value (Totox) was calculated according to the formula described by (Shahidi and Wanasundara, 2002).

$$
\text { Totox value }=2 \text { P.V }+ \text { An. } . \text { }
$$

Where: P.V is the peroxide value and An.V is the anisidine value.

\section{RESULTS AND DISCUSSION}

1) Irrigation requirements: The effect of water irrigation under two drip irrigation systems with two varieties of sunflower seeds (Saka 53, and Giza 102) on yield related to (2013) and (2014) seasons.

Table (3): Water used in all season, $\mathrm{m}^{3} / \mathrm{fed}$

\begin{tabular}{|l|c|c|c|c|c|}
\hline $\begin{array}{c}\text { Sunflowe Water } \\
\text { used } \mathbf{~ m}^{\mathbf{3}} \text { /fed }\end{array}$ & $\begin{array}{c}\text { Control } \\
\mathbf{m}^{\mathbf{3}} / \mathbf{f e d}\end{array}$ & $\begin{array}{c}\mathbf{1 0 0 \%} \\
\mathbf{m}^{\mathbf{3}} / \mathbf{f e d}\end{array}$ & $\begin{array}{c}\mathbf{8 0 \%} \\
\mathbf{m}^{\mathbf{3}} / \mathbf{f e d}\end{array}$ & $\begin{array}{c}\mathbf{6 0 \%} \\
\mathbf{m}^{\mathbf{3}} / \mathbf{f e d}\end{array}$ & $\begin{array}{c}\mathbf{5 0 \%} \\
\mathbf{m}^{\mathbf{3}} / \mathbf{f e d}\end{array}$ \\
\hline \hline Giza 2013 & 3800 & 1662 & 1330 & 997 & 831 \\
\hline Saka 2013 & 3900 & 2153 & 1722 & 1292 & 1077 \\
\hline Giza 2014 & 3800 & 1618 & 1294 & 971 & 809 \\
\hline Saka 2014 & 3900 & 1968 & 1574 & 1181 & 934 \\
\hline
\end{tabular}

2) WUE of seed yield: Water productivity (WP) expresses a physical ratio between yield and water use, Results in fig (2) indicate that in the $1^{\text {st }}$ season (2013), variety Saka53 WUE was greater in (SSDI) than (SDI). Also for variety Giza102 WUE was greater in (SSDI) than (SDI) and the least value was of WUE control treatment Giza102. The highest value of WUE of Giza102 was when applying water at $50 \%$ of the ETo of SSDI. In fig (3) the $2^{\text {nd }}$ season (2014) variety Saka53, WUE was greater in (SSDI) than (SDI). Also, variety Giza102, WUE was greater in (SSDI) than (SDI). The least value of WUE was at the control treatment Giza102 .The highest 
value was WUE of Saka53 when applying water at $60 \%$ of the ETo (SSDI).

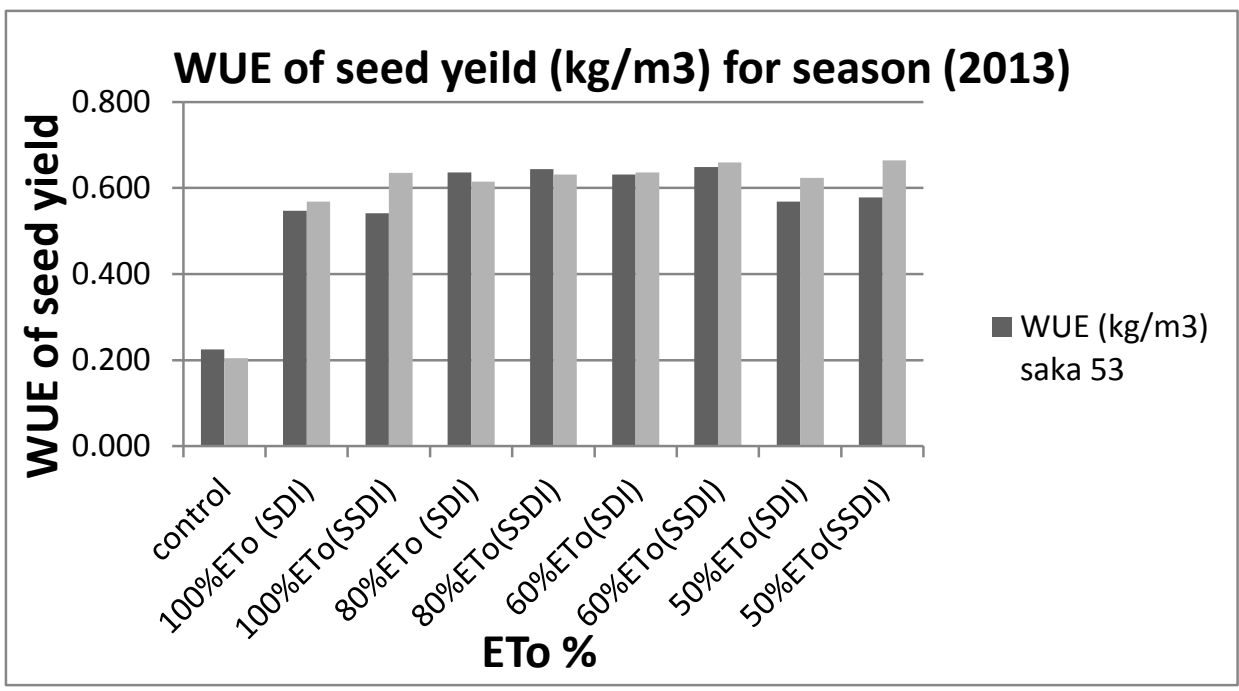

Fig. (2) WUE of seed yield (kg/m3) for sunflower season (2013).

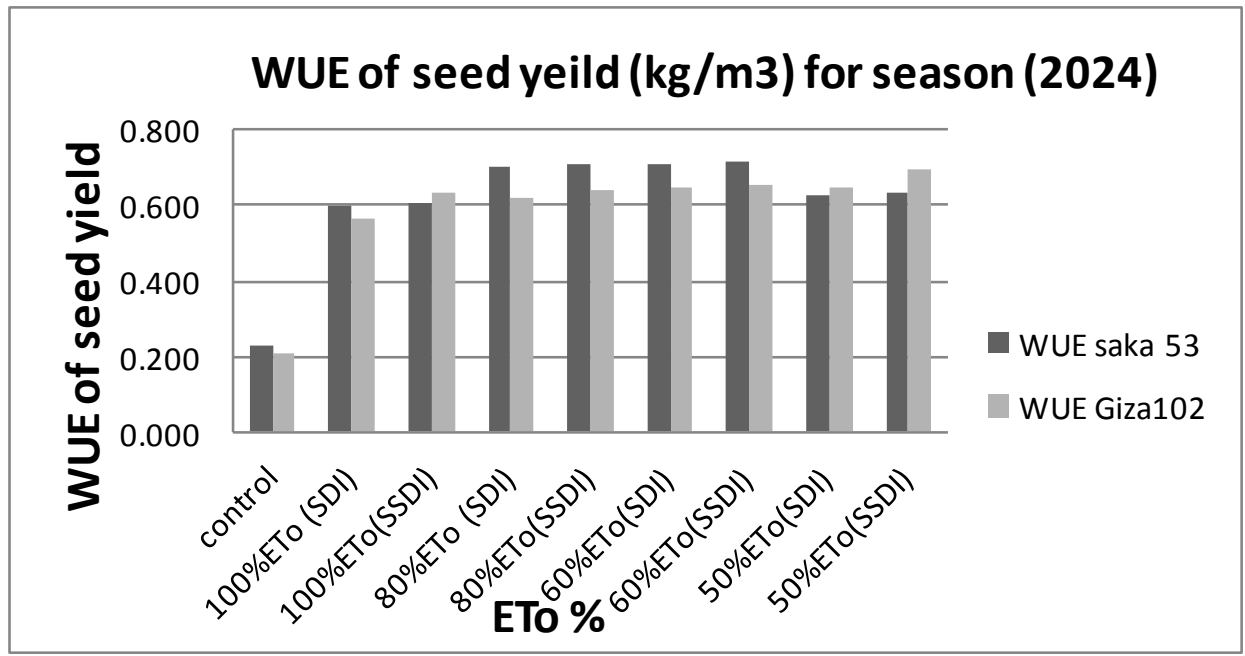

Fig. (3) WUE of seed yield (kg/m3) for sunflower season (2014). 
3) WUE of oil yield: Results of fig (5) indicate that, in the $1^{\text {st }}$ season, generally, variety Saka53, WUE of oil was greater in (SSDI) than (SDI). Also, for variety Giza102, WUE was greater in (SSDI) than (SDI) and the least value of WUE for oil was of variety Giza102 control treatment. The highest value WUE of Saka53, was when applying water at $80 \%$ of the ETo of (SSDI).

In fig (6) the $2^{\text {nd }}$ season, variety Saka53, WUE was greater in (SSDI) than (SDI). Also, for variety Giza102, WUE was greater in (SSDI) than (SDI). The least value of WUE was for control treatment of Giza102.The highest value of WUE for Saka53 was when applying water at $80 \%$ of the ETo (SSDI). In fig .7, the average of two seasons, of WUE seed yield of Saka 53 was when applying water at $80 \%$ of the ETo (SSDI) and the least value of WUE for Giza102 was for the control treatment.

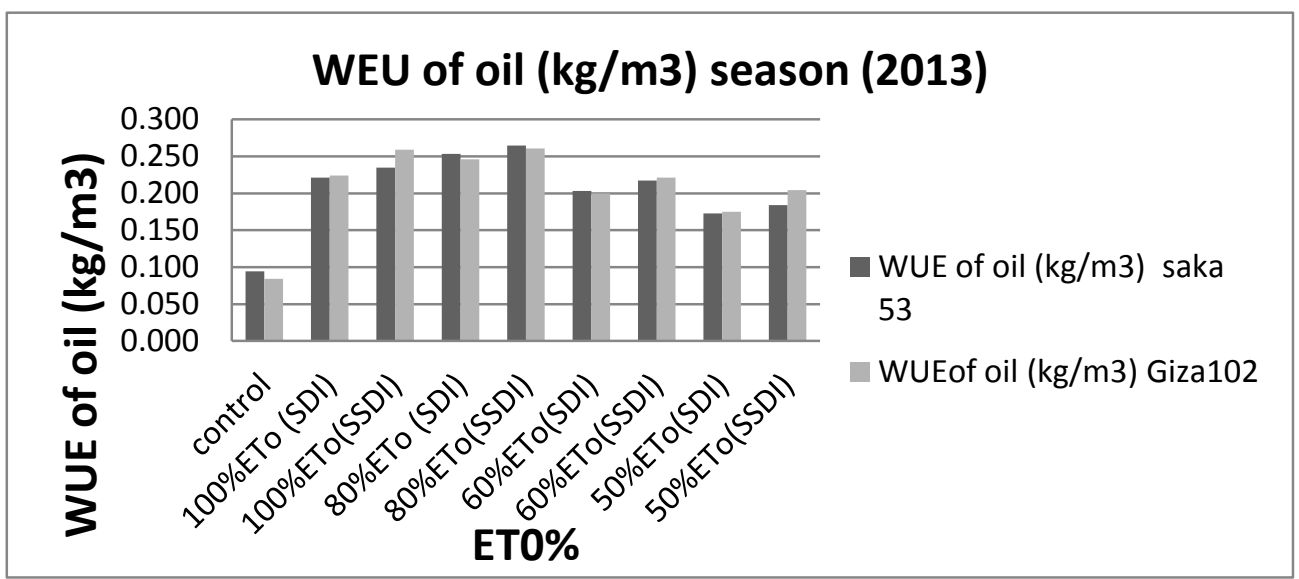

Fig. (4) Water use efficiency of oil seed yield $(\mathrm{kg} / \mathrm{m} 3)$ sunflower season (2013). 


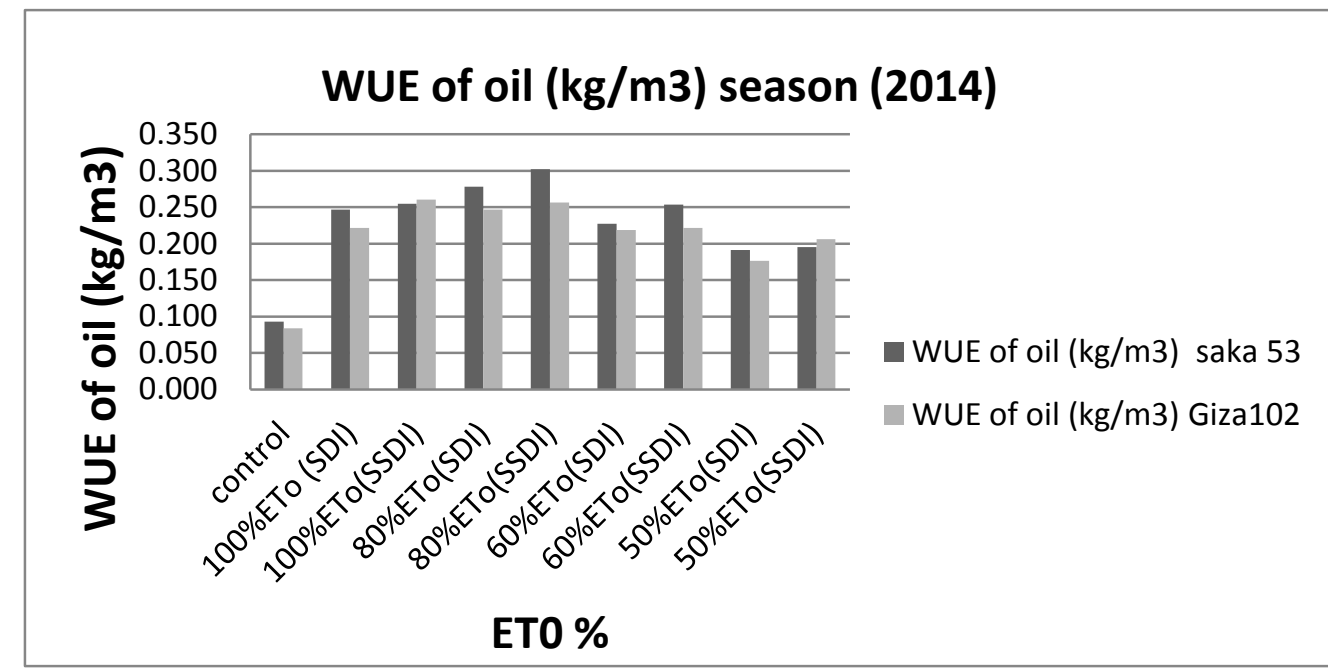

Fig. (5) Water use efficiency of oil seed yield $(\mathrm{kg} / \mathrm{m} 3)$ sunflower season (2014).

4) The crop production: Fig .6: shows curves of the seed yield and total applied water.

1) Water crop relation for season (2013) for Saka 53:

Surface drip irrigation (SDI). $\quad \mathrm{Y}=0.0002 \mathrm{x}^{2}+1.3381 \mathrm{x}-516.96$

Subsurface drip irrigation (SSDI). $\mathrm{Y}=0.0002 \mathrm{x}^{2}+1.2899 \mathrm{x}-454.34$

2) Water crop function season (1) Giza102.

Surface drip irrigation (SDI). $\quad Y=0.0002 x^{2}+0.9965 x-170.72$

Subsurface drip irrigation (SSDI). $\mathrm{Y}=0.0002 \mathrm{x}^{2}+1.1757 \mathrm{x}-277.82$

Integrating the different trials, yield and yield components respond to several parameters, such as stress, water or irrigation applied are determined in Fig .7. Yield relationship with crop water stress (considering averaged KsFG parameter), with the percentage of optimal water requirements, and with 
the percentage of optimal irrigation requirements generated logarithmic curves with R2 equal to $0.9796,0.9654,0.9991$ and 0.9874 respectively.

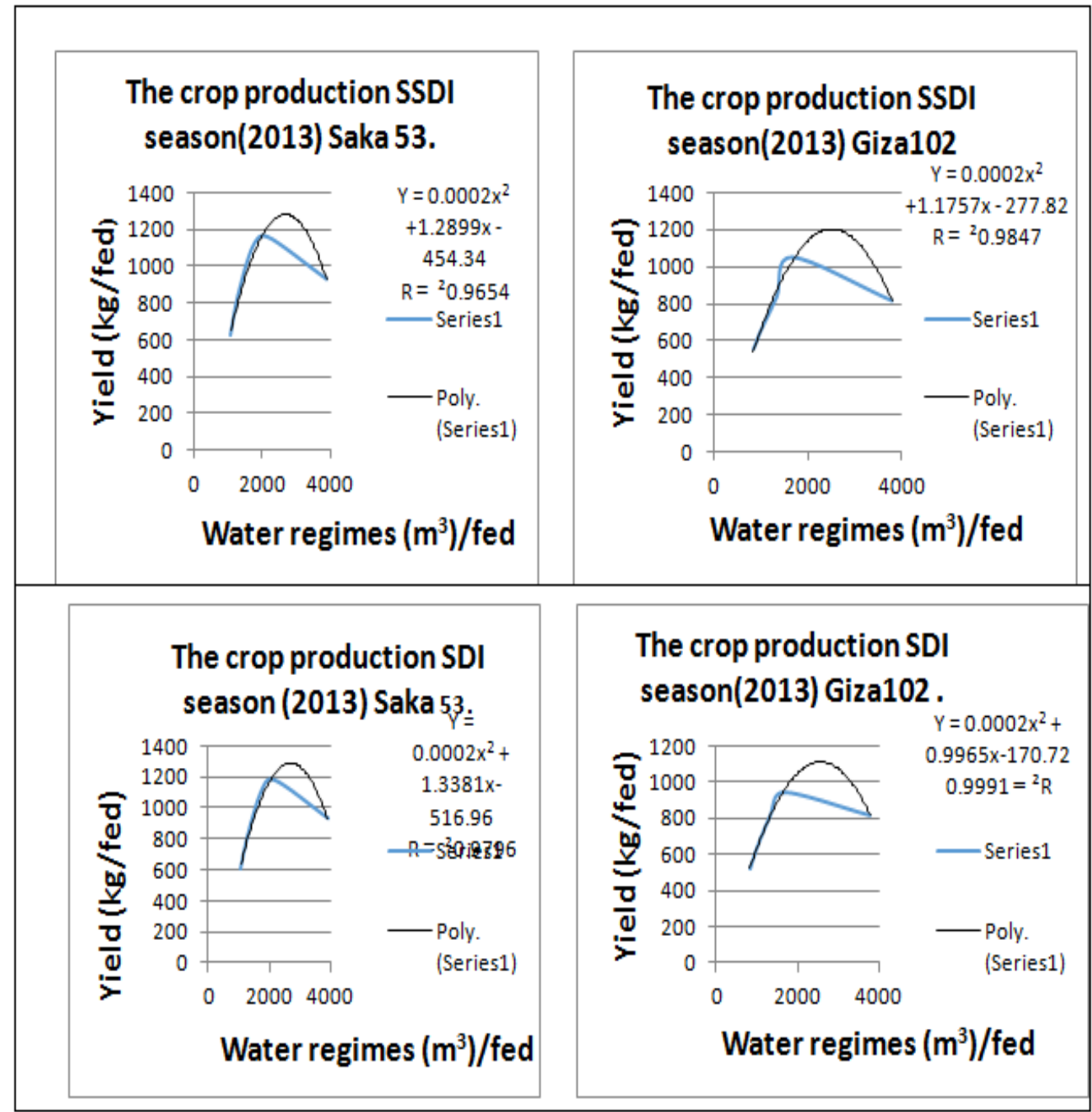

Fig (6) The crop production rate in season (2013). 
Fig (7) indicates curves of the seed yield and total applied water.

1) Water crop function for season (2)., Saka 53:

Surface drip irrigation (SDI). $\quad Y=0.0002 x^{2}+1.3318 x-477.89$

Subsurface drip irrigation (SSDI). $\mathrm{Y}=0.0003 \mathrm{x}^{2}+1.3486 \mathrm{x}-484.34$

2) Water crop function for season (2)., Giza102.

Surface drip irrigation (SDI). $\quad \mathrm{Y}=0.0002 \mathrm{x}^{2}+0.929 \mathrm{x}-105.92$

Subsurface drip irrigation (SSDI). $\mathrm{Y}=0.0002 \mathrm{x}^{2}+1.2512 \mathrm{x}-357.34$

Integrating the different trials, yield and yield components respond to several parameters, such as stress, water or irrigation is determined in (Fig. 10). Yield relationship with crop water stress, with the $\%$ age of optimal water requirements, and with the $\%$ age of optimal irrigation requirements generated relations with $\mathrm{R} 2=0.9713,0.9612,0.9983$ and 0.9951 respectively. This result agrees with Lorite et al. (2007) and Rinaldi (2001) which coincides with volumes of around $2000 \mathrm{~m} 3 \mathrm{ha}-1$ to obtain the highest profitability. 
J. Environ. Sci.

Institute of Environmental Studies and Research - Ain Shams University

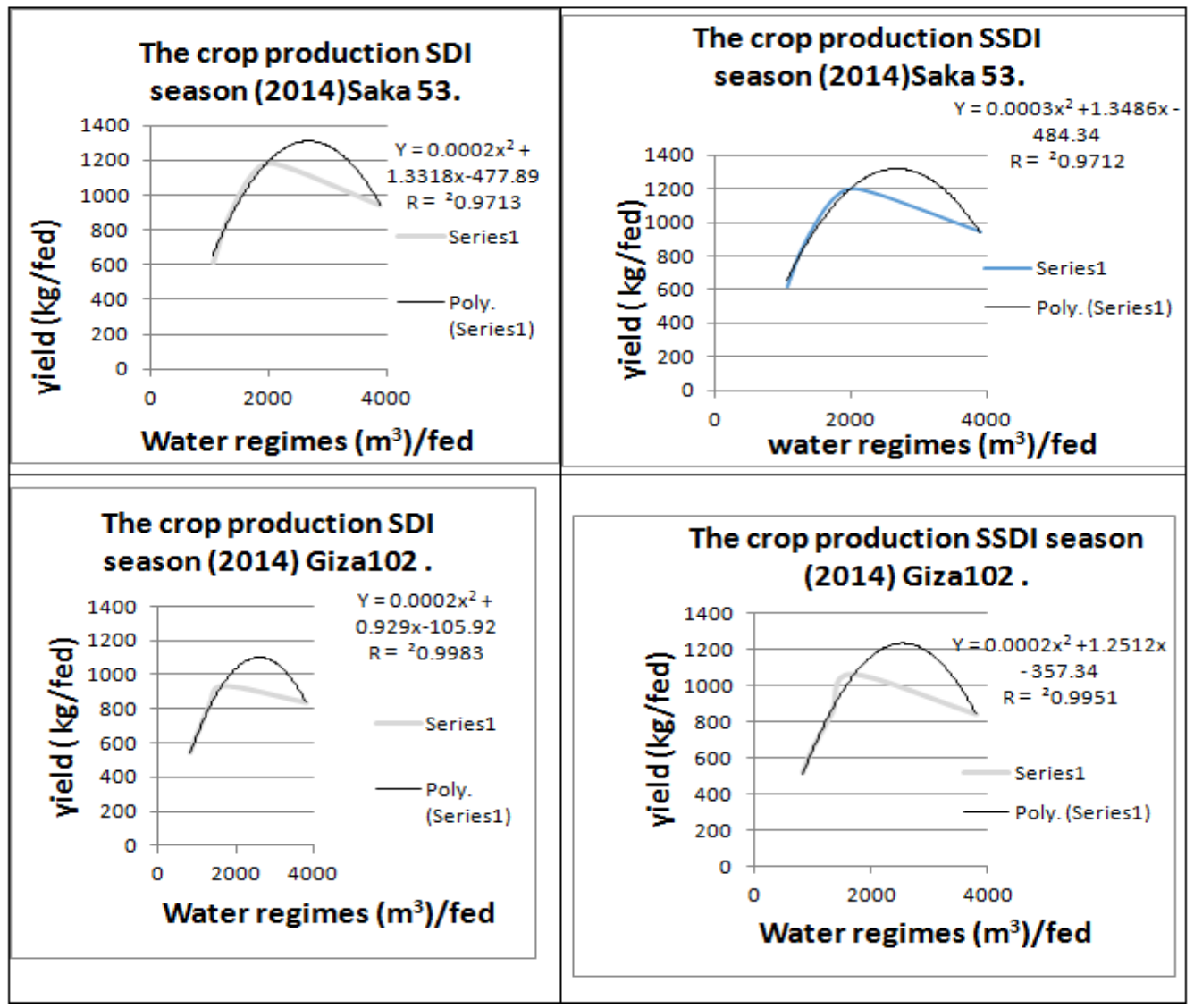

Fig (7) The crop production in season (2014).

5) Effect of the irrigation treatments on seed yield: From table (4), the effect of irrigation treatments on seed yield is in the order of $(100 \% 80 \% 60 \% 50 \%)$ from $\mathrm{K}_{\mathrm{c}}$. The yield at $100 \%$ was always higher than $80 \%, 60 \%$, and $50 \%$. This means that decreasing irrigation water to $80 \%$ of the net water requirement or less reduces the seed yield by more than 50\%. Shinde et al. (1987) and Cox\& Jalliff (1986) found similar results. Significant differences were detected regarding the effect of irrigation 
method on yield of sunflower seed of two varieties of Sunflower Saka 53 and Giza 102. The difference in productivity between the two varieties is due to genetic traits. Murriel (1975) reported that the highest seed yield was obtained from a treatment having no water stress, whereas the lowest yield was from a non-irrigated application. One of the most important features of subsurface drip irrigation (SSDI) is its potential in saving water comparing with surface drip irrigation system (SDI).

Table (4): The water regimes $\left(\mathrm{m}^{3}\right)$ and crop production seed yield in season (2013, 2014).

\begin{tabular}{|l|c|c|c|c|}
\hline \hline \multirow{2}{*}{ Irrigation treatments } & \multicolumn{2}{|c|}{ Water regimes $\left.\mathbf{( m}^{\mathbf{3}}\right)$} & \multicolumn{2}{c|}{ Seed yield ( kg/fed) } \\
\cline { 2 - 5 } & $\begin{array}{c}\text { Season } \\
\mathbf{( 2 0 1 3 )}\end{array}$ & $\begin{array}{c}\text { Season } \\
\mathbf{( 2 0 1 4 )}\end{array}$ & $\begin{array}{c}\text { Season } \\
\mathbf{( 2 0 1 3 )}\end{array}$ & $\begin{array}{c}\text { Season } \\
(\mathbf{2 0 1 4})\end{array}$ \\
\hline \hline Saka53 control & 3900 & 3900 & 933 & 945 \\
\hline Saka53 100\% SDI & 2155 & 2106 & 1178 & 1184 \\
\hline Saka53 100\%SSDI & 2155 & 2106 & 1166 & 1195 \\
\hline Saka53 80\%SDI & 1724 & 1685 & 1096 & 1108 \\
\hline Saka53 80\%SSDI & 1724 & 1685 & 1108 & 1120 \\
\hline Saka53 60\%SDI & 1293 & 1264 & 815 & 836 \\
\hline Saka53 60\%SSDI & 1293 & 1264 & 838 & 844 \\
\hline Saka53 50\%SDI & 1078 & 1053 & 612 & 615 \\
\hline Saka53 50\%SSDI & 1078 & 1053 & 623 & 622 \\
\hline Giza102 control & 3800 & 3800 & 817 & 840 \\
\hline Giza102 100\% SDI & 1662 & 1670 & 945 & 939 \\
\hline Giza102100\% SSDI & 1662 & 1670 & 1055 & 1061 \\
\hline Giza102 80\% SDI & 1330 & 1336 & 817 & 826 \\
\hline Giza102 80\% SSDI & 1330 & 1336 & 840 & 851 \\
\hline Giza102 60\% SDI & 997 & 1002 & 635 & 646 \\
\hline Giza102 60\% SSDI & 997 & 1002 & 658 & 652 \\
\hline Giza102 50\% SDI & 831 & 835 & 518 & 541 \\
\hline Giza102 50\%SSDI & 831 & 835 & 552 & 583 \\
\hline
\end{tabular}


J. Environ. Sci.

Institute of Environmental Studies and Research - Ain Shams University 
6) Effect of the irrigation treatment systems on oil characteristics: Table (5) shows the interaction between irrigation systems water regimes and two hybrid sunflowers (Giza 102 and Saka 53) on oil characteristics in the first and second seasons. All oil characteristics had significant response to the interaction between the three experimental factors:

\section{7) Physico-chemical characteristics of sunflower seeds Giza102 and Saka}

53: Oil percentage, an important quality component in sunflower, was processed by irrigation treatments applied at different growth stages. Mean oil percentages varied from $43.40 \%$ to $27.2 \%$ in the two varieties of Sunflower Saka 53 and Giza 102 in the two seasons. It is clear from Table (5) for seasons (2013) and (2014) that subsurface drip irrigation (SSDI) oil percentage was higher than surface drip irrigation (SDI) with furrow irrigation. On the other hand, sunflower variety Saka 53 was superior then Giza 102 in the two seasons in oil percentage. There are differences in the percentage of oil in the same sunflower variety in the first and second seasons. Seed oil percentage is significantly related to water stress.

A possible factor causing the variable results was water stress during the seed development stage. That agrees with the results of Unger and Thompson, (1982), and explained by Davidescu et al., (1977). Irrigation caused at slightly different growth stages, thus differences in oil percentages in the seed. Also, different irrigation treatments caused water stress in plants, and different transpiration rates and possibly different plant temperatures. 
J. Environ. Sci.

Institute of Environmental Studies and Research - Ain Shams University

Table (5): Seed sunflower composition (Moisture, Protein, Oil, Ash and NFE* for Giza102 and Saka 53 in season (2013).

\begin{tabular}{|l|c|c|c|c|c||}
\hline \multicolumn{7}{|c|}{ Giza102 } \\
\hline Irrigation treatments & Moisture & Protein & Oil & Ash & NFE $^{*}$ \\
\hline \hline Giza102 control & $6.80^{\mathrm{a}}$ & $10.20^{\mathrm{c}}$ & $41.00^{\mathrm{ab}}$ & $4.00^{\mathrm{b}}$ & $38.00^{\mathrm{c}}$ \\
\hline Giza102 100\% SDI & $6.60^{\mathrm{ab}}$ & $11.30^{\mathrm{ab}}$ & $40.41^{\mathrm{b}}$ & $4.40^{\mathrm{a}}$ & $37.28^{\mathrm{c}}$ \\
\hline Giza102 100\% SSDI & $6.50^{\mathrm{ab}}$ & $10.80^{\mathrm{b}}$ & $43.40^{\mathrm{a}}$ & $4.20^{\mathrm{ab}}$ & $35.10^{\mathrm{c}}$ \\
\hline Giza102 80\% SDI & $6.30^{\mathrm{abc}}$ & $11.70^{\mathrm{a}}$ & $39.80^{\mathrm{b}}$ & $4.10^{\mathrm{ab}}$ & $38.10^{\mathrm{c}}$ \\
\hline Giza102 80\% SSDI & $6.10^{\mathrm{abcd}}$ & $11.50^{\mathrm{a}}$ & $41.10^{\mathrm{ab}}$ & $4.20^{\mathrm{ab}}$ & $37.10^{\mathrm{c}}$ \\
\hline Giza102 60\% SDI & $5.80^{\mathrm{bcd}}$ & $10.10^{\mathrm{c}}$ & $32.20^{\mathrm{cd}}$ & $4.00^{\mathrm{b}}$ & $47.90^{\mathrm{ab}}$ \\
\hline Giza102 60\% SSDI & $6.10^{\mathrm{abcd}}$ & $10.80^{\mathrm{b}}$ & $33.50^{\mathrm{c}}$ & $4.10^{\mathrm{ab}}$ & $45.50^{\mathrm{b}}$ \\
\hline Giza102 50\% SDI & $5.30^{\mathrm{d}}$ & $10.50^{\mathrm{a}}$ & $30.40^{\mathrm{d}}$ & $4.00^{\mathrm{b}}$ & $48.80^{\mathrm{a}}$ \\
\hline Giza102 50\%SSDI & $5.50^{\mathrm{cd}}$ & $10.00^{\mathrm{c}}$ & $31.80^{\mathrm{cd}}$ & $3.30^{\mathrm{c}}$ & $49.40^{\mathrm{a}}$ \\
\hline \hline \multicolumn{7}{|c|}{ Saka 53 } & \multicolumn{3}{|c|}{} \\
\hline \hline Saka53 control & $6.0^{\mathrm{ab}}$ & $10.40^{\mathrm{bc}}$ & $41.20^{\mathrm{a}}$ & $4.10^{\mathrm{ab}}$ & $38.30^{\mathrm{c}}$ \\
\hline Saka53 100\% SDI & $6.40^{\mathrm{a}}$ & $10.50^{\mathrm{bc}}$ & $41.20^{\mathrm{a}}$ & $3.40^{\mathrm{d}}$ & $40.30^{\mathrm{c}}$ \\
\hline Saka53 100\%SSDI & $6.20^{\mathrm{a}}$ & $9.70^{\mathrm{d}}$ & $40.80^{\mathrm{a}}$ & $3.50^{\mathrm{cd}}$ & $39.80 \mathrm{c}$ \\
\hline Saka53 80\%SDI & $5.30^{\mathrm{bc}}$ & $10.80^{\mathrm{b}}$ & $40.10^{\mathrm{a}}$ & $3.80^{\mathrm{bc}}$ & $40.00^{\mathrm{c}}$ \\
\hline Saka53 80\%SSDI & $5.20^{\mathrm{c}}$ & $11.60^{\mathrm{a}}$ & $41.30^{\mathrm{a}}$ & $4.00^{\mathrm{ab}}$ & $37.90^{\mathrm{c}}$ \\
\hline Saka53 60\%SDI & $5.10^{\mathrm{c}}$ & $10.00^{\mathrm{cd}}$ & $31.40^{\mathrm{bc}}$ & $4.10^{\mathrm{ab}}$ & $49.40^{\mathrm{b}}$ \\
\hline Saka53 60\%SSDI & $5.10^{\mathrm{c}}$ & $9.90^{\mathrm{cd}}$ & $33.60^{\mathrm{b}}$ & $4.00^{\mathrm{ab}}$ & $47.40^{\mathrm{b}}$ \\
\hline Saka53 50\%SDI & $5.00^{\mathrm{c}}$ & $9.90^{\mathrm{cd}}$ & $28.10^{\mathrm{d}}$ & $4.20^{\mathrm{a}}$ & $52.80^{\mathrm{a}}$ \\
\hline Saka53 50\%SSDI & $5.10^{\mathrm{c}}$ & $9.90^{\mathrm{bc}}$ & $30.80^{\mathrm{c}}$ & $3.80^{\mathrm{bc}}$ & $49.90^{\mathrm{b}}$ \\
\hline
\end{tabular}

Means with the same letter in the column had non- significant differences $(\mathrm{P}>0.05)$ -

Surface drib irrigation (SDI). Subsurface drip irrigation (SSDI).

$*=$ calculated by difference $=$ Nitrogen free extract. 
Table (6): Sunflower seed composition (Moisture, Protein, Oil, Ash and NFE*for Giza102 and Saka53 in season (2014).

\begin{tabular}{|l|c|c|c|c|c||}
\hline \multicolumn{7}{|c|}{ Giza102 } \\
\hline \hline Irrigation treatments & Moisture & Protein & Oil & Ash & NFE $^{*}$ \\
\hline Giza102 control & $6.70^{\mathrm{a}}$ & $9.60^{\mathrm{e}}$ & $39.90^{\mathrm{a}}$ & $3.00^{\mathrm{b}}$ & $40.80^{\mathrm{c}}$ \\
\hline Giza102 100\% SDI & $6.70^{\mathrm{a}}$ & $11.60^{\mathrm{b}}$ & $39.40^{\mathrm{a}}$ & $4.00^{\mathrm{a}}$ & $38.30^{\mathrm{bc}}$ \\
\hline Giza102 100\% SSDI & $6.70^{\mathrm{a}}$ & $11.80^{\mathrm{b}}$ & $41.00^{\mathrm{a}}$ & $4.00^{\mathrm{a}}$ & $36.50^{\mathrm{d}}$ \\
\hline Giza102 80\% SDI & $6.00^{\mathrm{b}}$ & $11.80^{\mathrm{b}}$ & $39.90^{\mathrm{a}}$ & $4.00^{\mathrm{a}}$ & $38.30^{\mathrm{cd}}$ \\
\hline Giza102 80\% SSDI & $5.80^{\mathrm{bc}}$ & $12.70^{\mathrm{a}}$ & $40.20^{\mathrm{a}}$ & $4.00^{\mathrm{a}}$ & $37.30^{\mathrm{d}}$ \\
\hline Giza102 60\% SDI & $6.00^{\mathrm{b}}$ & $10.40^{\mathrm{d}}$ & $33.90^{\mathrm{b}}$ & $4.00^{\mathrm{a}}$ & $45.70^{\mathrm{b}}$ \\
\hline Giza102 60\% SSDI & $6.00^{\mathrm{b}}$ & $11.80^{\mathrm{b}}$ & $34.00^{\mathrm{b}}$ & $4.00^{\mathrm{a}}$ & $44.20^{\mathrm{b}}$ \\
\hline Giza102 50\% SDI & $5.53^{\mathrm{d}}$ & $10.90^{\mathrm{c}}$ & $27.20^{\mathrm{d}}$ & $4.00^{\mathrm{a}}$ & $52.36^{\mathrm{a}}$ \\
\hline Giza102 50\%SSDI & $5.40^{\mathrm{d}}$ & $10.06^{\mathrm{d}}$ & $29.50^{\mathrm{c}}$ & $3.00^{\mathrm{b}}$ & $52.03^{\mathrm{a}}$ \\
\hline \hline \multicolumn{7}{|c|}{ Saka53 } & \\
\hline Saka53 control & $6.06^{\mathrm{b}}$ & $10.30^{\mathrm{c}}$ & $40.80^{\mathrm{ab}}$ & $3.83^{\mathrm{a}}$ & $43.39^{\mathrm{c}}$ \\
\hline Saka53 100\% SDI & $6.70^{\mathrm{a}}$ & $10.10^{\mathrm{cd}}$ & $41.00^{\mathrm{ab}}$ & $3.00^{\mathrm{b}}$ & $44.28^{\mathrm{c}}$ \\
\hline Saka53 100\%SSDI & $6.60^{\mathrm{a}}$ & $9.84^{\mathrm{d}}$ & $42.10^{\mathrm{a}}$ & $3.00^{\mathrm{b}}$ & $43.36^{\mathrm{c}}$ \\
\hline Saka53 80\%SDI & $5.00^{\mathrm{c}}$ & $11.20^{\mathrm{b}}$ & $39.50^{\mathrm{b}}$ & $4.00^{\mathrm{a}}$ & $43.28^{\mathrm{c}}$ \\
\hline Saka53 80\%SSDI & $5.00^{\mathrm{c}}$ & $11.80^{\mathrm{a}}$ & $42.50^{\mathrm{a}}$ & $4.00^{\mathrm{a}}$ & $40.47^{\mathrm{d}}$ \\
\hline Saka53 60\%SDI & $5.00^{\mathrm{c}}$ & $12.00^{\mathrm{a}}$ & $32.10^{\mathrm{c}}$ & $4.00^{\mathrm{a}}$ & $50.55^{\mathrm{b}}$ \\
\hline Saka53 60\%SSDI & $5.00^{\mathrm{c}}$ & $10.30^{\mathrm{c}}$ & $32.50^{\mathrm{c}}$ & $3.00^{\mathrm{b}}$ & $52.73^{\mathrm{b}}$ \\
\hline Saka53 50\%SDI & $5.00^{\mathrm{c}}$ & $10.94^{\mathrm{b}}$ & $30.60^{\mathrm{c}}$ & $3.00^{\mathrm{b}}$ & $55.46^{\mathrm{a}}$ \\
\hline Saka53 50\%SSDI & $5.00^{\mathrm{c}}$ & $10.06^{\mathrm{cd}}$ & $30.90^{\mathrm{c}}$ & $3.00^{\mathrm{b}}$ & $56.03^{\mathrm{a}}$ \\
\hline
\end{tabular}

Means with the same latter in the column had non- significant differences $(\mathrm{P}>0.05)$ Surface drib irrigation (SDI). Subsurface drip irrigation (SSDI). $*=$ calculated by difference $=$ Nitrogen free extract.

\section{8) Physico-chemical characteristics of sunflower oils of Giza102 and Saka}

53.: Physico-chemical characteristics of different oil samples were extradited from sunflower crop treated under different irrigation methods during seasons 2013 and 2014 and presented in table $(6,7)$. 
In season (2013), Giza 102 had the highest Acid value (AV) mg KOH compared with the control sample .The lowest AV mgKOH was observed 0.94 by using $100 \%$ SSDI of $\mathrm{ET}_{0}$. Saka 53 had the highest AV $\mathrm{mgKOH}$ as observed 1.71 obtained by using control. The lowest AV mg KOH was observed 0.98 by using 100\% SSDI of ETo. At season (2014) Giza 102 had the highest AV which was 1.25 obtained by using 50\% SDI of ETo. The lowest AV KOH/g was observed 1.02 by using 100\% SSDI of ET0. Saka 53. The highest AV KOH/g was observed as 1.18 obtained by using $60 \%$ SSDI of ETo. The lowest AV KOH/g was observed 0.89 by using $80 \%$ SSDI of ETo. Abitogun and Oshodi (2010) found that acid value content was 2.78 $\mathrm{mg} \mathrm{KOH/g}$ oil sunflowers. Lamas et al. (2016) noted that the acidity of crude oil sunflower is accepted among $2.290 \pm 0.050$ (mg KOH/g oil).

At season (2013), Giza 102 had the highest Peroxide value PV meq. $\mathrm{O}_{2} / \mathrm{kg}$ oil as 3.88 obtained by using $50 \%$ SSDI of ETo. The lowest PV meq. $\mathrm{O}_{2} / \mathrm{kg}$ oil was 3.17 by using $80 \%$ SSDI of ETo. Saka 53 had the highest PV meq. $\mathrm{O}_{2} / \mathrm{kg}$ oil that was 3.99 obtained by using $60 \%$ SSDI of ETo. The lowest PV meq. $\mathrm{O}_{2} / \mathrm{kg}$ oil was 3.26 by using $60 \%$ SDI of ETo. At season (2014) Giza 102 had the highest PV meq. $\mathrm{O}_{2} / \mathrm{kg}$ oil as 4.54 obtained by using $50 \%$ SSDI of ETo. The lowest PV meq. $\mathrm{O}_{2} / \mathrm{kg}$ oil was 2.86 by using $80 \%$ SSDI of ET0. Saka 53 had the highest PV meq. $\mathrm{O}_{2} / \mathrm{kg}$ oil at 4.55 obtained by using 50\% SDI of ETo. The lowest PV meq. $\mathrm{O}_{2} / \mathrm{kg}$ oil was for oil 2.71 by using $80 \%$ SDI of ET0. For proper handling, Gupta (2003) suggested to maintain a peroxide value of less than 4 in the crude oil during storage. Lamas et,al (2016) The Peroxide value, PV (meq. $\mathrm{O}_{2} / \mathrm{kg}$ ) for crude oil 
sunflower is $3.660 \pm 0.160$. At season (2013), Giza 102 had the highest Anisidine value. AnV meq. $/ \mathrm{kg}$ oil was 2.07 obtained by using control. The lowest AnV meq./kg oil was 1.21by using 100\% SSDI of ET0. Saka 53 had the highest $\mathrm{AnV}$ meq./kg oil which was 2.89 obtained by using 100\%SSDI of ETo. The lowest AnV meq./kg oil was 1.63 by using 60\%SDI of ET0. At season (2014), Giza 102 had the highest AnV meq./kg oil, which was 2.03obtained by using $80 \%$ SDI of ETo . The lowest AnV meq./kg oil was 1.14 by using $60 \%$ SDI of ET0. Saka 53 had the highest AnV meq./kg oil which was 2.42 obtained by using 100\% SSDI of ETo. The lowest AnV meq. $/ \mathrm{kg}$ oil was 1.24 by using $60 \%$ SDI of ETo. RI and IV values were indicative of unsaturation levels and as a result oil' tendency to undergo autoxidation (Farhoosh et al., 2008). Decreased levels of unsaturation (linoleic acid) will result in increased levels of oxidative stability. The PV and p-An $\mathrm{V}$ gave an indication of the initial oxidative status of the extracted oil samples. The use of $\mathrm{PV}$ and $\mathrm{AN}$.V together provides a comprehensive overview of the oxidation process in oils. This is a mathematical prediction of oxidative stability and the value is calculated as TOTOX value was used as an indication of overall oxidative stability and was correlated with the extent of oil deterioration (Zhang et al.) 2010 and (De Abreu et al.) 2010. At season (2013), Giza 102 gave the highest TOTOX which was 9.26 obtained by using $50 \%$ SSDI of ETo. The lowest TOTOX was 7.72 by using $80 \%$ SSDI of ETo. Saka 53 gave the highest TOTOX which was 10.84 obtained by using $80 \%$ SSDI of ETo. The lowest TOTOX was 8.13 by using $60 \%$ SDI of ETo. At (2014) season, Giza 102 gave the highest TOTOX which was 10.55 obtained by using 50\%SSDI of ETo. The lowest TOTOX which was 7.74 by 
J. Environ. Sci.

Institute of Environmental Studies and Research - Ain Shams University

using $80 \%$ SSDI of ETo. Saka 53 gave the highest TOTOX which was 11.26 obtained by using 50\% SDI of ET0. The lowest TOTOX was 6.61by using $60 \%$ SDI of ETo. Refractive indexes at $20^{\circ} \mathrm{C}$. at season (2013) for Giza 102 and Saka 53, at all treatments were not different.

Table (7): Physico-chemical characteristics of sunflower oil extracted from seed Giza102 and Saka 53 for irrigation requirements in season (2013).

\begin{tabular}{|c|c|c|c|c|c|}
\hline \multicolumn{6}{|c|}{ Giza102 } \\
\hline $\begin{array}{l}\text { Irrigation } \\
\text { treatments }\end{array}$ & $\begin{array}{c}\text { AV mg } \\
\mathrm{KOH} / \mathrm{g} \\
\text { oil }\end{array}$ & $\begin{array}{c}\text { PV } \\
\text { meq.O } \\
\text { /kg oil }\end{array}$ & $\begin{array}{c}\text { AnV } \\
\text { meq./kg }\end{array}$ & TOTOX & $\mathbf{R I} *$ \\
\hline Giza102 control & $1.19^{\mathrm{a}}$ & $3.28^{\mathrm{b}}$ & $2.07^{\mathrm{a}}$ & $8.63^{\mathrm{cb}}$ & 1.4849 \\
\hline Giza102 100\% SDI & $1.02^{\mathrm{cd}}$ & $3.22^{b}$ & $1.66^{\mathrm{cb}}$ & $8.10^{\mathrm{cbd}}$ & 1.4842 \\
\hline Giza102 100\% SSDI & $0.94^{\mathrm{d}}$ & $3.31^{\mathrm{b}}$ & $1.21^{\mathrm{d}}$ & $7.85^{\mathrm{cd}}$ & 1.4847 \\
\hline Giza102 80\% SDI & $1.08^{\mathrm{cd}}$ & $3.35^{\mathrm{b}}$ & $1.49^{\mathrm{cb}}$ & $8.20^{\mathrm{cbd}}$ & 1.4748 \\
\hline Giza102 80\% SSDI & $0.97^{\mathrm{d}}$ & $3.17^{\mathrm{b}}$ & $1.36^{\mathrm{cd}}$ & $7.72^{\mathrm{d}}$ & 1.4751 \\
\hline Giza102 60\% SDI & $1.11^{\mathrm{b}}$ & $3.50^{\mathrm{b}}$ & $2.00^{\mathrm{ab}}$ & $9.00^{\mathrm{a}}$ & 1.4747 \\
\hline Giza102 60\% SSDI & $1.02^{\mathrm{cbd}}$ & $3.49^{\mathrm{b}}$ & $1.70^{\mathrm{cb}}$ & $8.68^{\mathrm{ab}}$ & 1.4745 \\
\hline Giza102 50\% SDI & $1.19^{\mathrm{A}}$ & $3.50^{\mathrm{b}}$ & $1.58^{\mathrm{cb}}$ & $8.58^{\mathrm{acb}}$ & 1.4743 \\
\hline Giza102 50\%SSDI & $1.06^{\mathrm{cb}}$ & $3.88^{\mathrm{a}}$ & $1.49^{\mathrm{cd}}$ & $9.26^{\mathrm{a}}$ & 1.4841 \\
\hline \multicolumn{6}{|c|}{ Saka 53} \\
\hline Saka53 control & $1.71^{\mathrm{a}}$ & $0.98^{\mathrm{cb}}$ & $2.06^{\mathrm{cb}}$ & $8.84^{\mathrm{cd}}$ & 1.4841 \\
\hline Saka53 100\% SDI & $1.31^{\mathrm{b}}$ & $3.46^{\mathrm{cb}}$ & $2.34^{\mathrm{cb}}$ & $9.26^{\mathrm{cbd}}$ & 1.4842 \\
\hline Saka53 100\%SSDI & $0.91^{\mathrm{de}}$ & $3.44^{\mathrm{cb}}$ & $2.89^{\mathrm{ab}}$ & $9.77^{\mathrm{acb}}$ & 1.4845 \\
\hline Saka53 80\%SDI & $1.16^{\mathrm{cb}}$ & $3.50^{\mathrm{cb}}$ & $1.63^{\mathrm{c}}$ & $8.64^{\mathrm{cd}}$ & 1.4839 \\
\hline Saka53 80\%SSDI & $0.85^{\mathrm{e}}$ & $3.63^{b}$ & $3.56^{\mathrm{a}}$ & $10.84^{\mathrm{a}}$ & 1.4835 \\
\hline Saka53 60\%SDI & $1.16^{\mathrm{cb}}$ & $3.26^{\mathrm{c}}$ & $1.61^{\mathrm{c}}$ & $8.13^{\mathrm{d}}$ & 1.4840 \\
\hline Saka53 60\%SSDI & $1.03^{\mathrm{cd}}$ & $3.99^{\mathrm{a}}$ & $2.27^{\mathrm{cb}}$ & $10.25^{\mathrm{ab}}$ & 1.4845 \\
\hline Saka53 50\%SDI & $1.06^{\mathrm{cd}}$ & $3.65^{b}$ & $2.13^{\mathrm{cb}}$ & $9.44^{\mathrm{bc}}$ & 1.4841 \\
\hline Saka53 50\%SSDI & $0.98^{\mathrm{de}}$ & $3.69^{b}$ & $1.92^{\mathrm{c}}$ & $9.31^{\text {bcd }}$ & 1.4846 \\
\hline
\end{tabular}

Means with the same latter in the column had non- significant differences ( $\mathrm{P}>0.05)$. *Refractive index at $20^{\circ} \mathrm{c}(\mathrm{RI})$, Surface drip irrigation (SDI). Subsurface drip irrigation (SSDI). 
Table (8): Physico-chemical characteristics of sunflower oil extracted from seed Giza102 and Saka 53 for irrigation requirements in season (2014).

\begin{tabular}{|c|c|c|c|c|c|}
\hline \multicolumn{6}{|c|}{ Giza102 } \\
\hline $\begin{array}{l}\text { Irrigation } \\
\text { treatments }\end{array}$ & $\begin{array}{c}\mathrm{AV} \mathrm{mg} \\
\mathrm{KOH} / \mathrm{g} \\
\text { oil }\end{array}$ & $\begin{array}{c}\text { PV } \\
\text { meq. } \mathrm{O}_{2} / \\
\mathrm{kg} \text { oil }\end{array}$ & $\begin{array}{c}\text { AnV } \\
\text { meq./ } \\
\text { kg }\end{array}$ & TOTOX & RI* \\
\hline Giza102 control & $1.22^{\mathrm{a}}$ & $3.29^{\mathrm{bc}}$ & $1.67^{\mathrm{ab}}$ & $8.26^{\mathrm{cd}}$ & 1.4750 \\
\hline Giza102 100\% SDI & $1.18^{\mathrm{ab}}$ & $4.23^{\mathrm{a}}$ & $1.41^{\mathrm{ab}}$ & $9.88^{\mathrm{ab}}$ & 1.4756 \\
\hline Giza102 100\% SSDI & $1.02^{\mathrm{bc}}$ & $3.54^{\mathrm{b}}$ & $1.53^{\mathrm{ab}}$ & $8.61^{\mathrm{bcd}}$ & 1.4753 \\
\hline Giza102 80\% SDI & $1.17^{\mathrm{abc}}$ & $3.35^{\mathrm{bc}}$ & $2.03^{\mathrm{a}}$ & $8.73^{\text {bcd }}$ & 1.4752 \\
\hline Giza102 80\% SSDI & $1.17^{\mathrm{c}}$ & $2.86^{\mathrm{c}}$ & $2.01^{\mathrm{a}}$ & $7.74^{\mathrm{d}}$ & 1.4753 \\
\hline Giza102 60\% SDI & $1.23^{\mathrm{a}}$ & $4.14^{\mathrm{a}}$ & $1.14^{\mathrm{b}}$ & $9.43^{\mathrm{abc}}$ & 1.4752 \\
\hline Giza102 60\% SSDI & $1.15^{\mathrm{abc}}$ & $4.33^{\mathrm{a}}$ & $1.24^{\mathrm{b}}$ & $9.90^{\mathrm{ab}}$ & 1.4752 \\
\hline Giza102 50\% SDI & $1.25^{\mathrm{a}}$ & $4.44^{\mathrm{a}}$ & $1.44^{\mathrm{ab}}$ & $10.34^{\mathrm{a}}$ & 1.4751 \\
\hline Giza102 50\%SSDI & $1.09^{\mathrm{abc}}$ & $4.54^{\mathrm{a}}$ & $1.47^{\mathrm{ab}}$ & $10.55^{\mathrm{a}}$ & 1.4750 \\
\hline \multicolumn{6}{|c|}{ Saka 53} \\
\hline Saka53 control & $1.84^{\mathrm{a}}$ & $3.45^{\mathrm{b}}$ & $1.56^{\mathrm{bc}}$ & $8.46^{\mathrm{cd}}$ & 1.4755 \\
\hline Saka53 100\% SDI & $1.35^{\mathrm{b}}$ & $3.57^{\mathrm{b}}$ & $2.14^{\mathrm{ab}}$ & $9.28^{\mathrm{bc}}$ & 1.4753 \\
\hline Saka53 100\%SSDI & $0.95^{\mathrm{d}}$ & $4.29^{\mathrm{a}}$ & $2.42^{\mathrm{a}}$ & $11.01^{\mathrm{a}}$ & 1.4757 \\
\hline Saka53 80\%SDI & $1.17^{\mathrm{bc}}$ & $2.71^{\mathrm{c}}$ & $2.08^{\mathrm{ab}}$ & $7.50^{\mathrm{de}}$ & 1.4743 \\
\hline Saka53 80\%SSDI & $0.89^{\mathrm{d}}$ & $4.35^{\mathrm{a}}$ & $1.84^{\mathrm{ab}}$ & $7.50^{\mathrm{a}}$ & 1.4742 \\
\hline Saka53 60\%SDI & $1.26^{\mathrm{b}}$ & $2.68^{\mathrm{c}}$ & $1.24^{\mathrm{c}}$ & $6.61^{\mathrm{e}}$ & 1.4742 \\
\hline Saka53 60\%SSDI & $1.18^{\mathrm{bc}}$ & $4.52^{\mathrm{a}}$ & $1.93^{\mathrm{ab}}$ & $10.98^{\mathrm{a}}$ & 1.4749 \\
\hline Saka53 50\%SDI & $0.99^{\mathrm{cd}}$ & $4.55^{\mathrm{a}}$ & $2.16^{\mathrm{ab}}$ & $11.26^{\mathrm{a}}$ & 1.4748 \\
\hline Saka53 50\%SSDI & $0.97^{\mathrm{cd}}$ & $4.24^{\mathrm{a}}$ & $1.79^{\mathrm{bc}}$ & $10.28^{\mathrm{ab}}$ & 1.4751 \\
\hline
\end{tabular}

Means with the same latter in the column had non- significant differences $(\mathrm{P}>0.05)$

$*$ Refractive index at $20^{\circ} \mathrm{c}$ (RI), Surface drip irrigation (SDI). Subsurface drip irrigation (SSDI). 
8-1 Fatty acid profile: Fatty acid profiles for different sunflower oil samples were extracted from seeds Saka 53 irrigated under different conditions presented in Table (8). The total saturated fatty acids mono unsaturated fatty acids and polyunsaturated fatty acids ranged between 10.4 to $11.9 \%$, 17.6 to $31.5 \%$ and 58.3 to $71.4 \%$ respectively. Total saturated fatty acids percentage, not affected by irrigation treatments, ranged between 50 to 100 $\%$ SDI or SSDI compared to the control samples. Also, the oil samples were extracted from sunflower seeds treated at $80 \%$ SDI, $80 \%$ SSDI and $60 \%$ SDI had 31.5, 28.0 and $31.3 \%$ for mono unsaturated fatty acids, respectively compared to the control sample that had $30.8 \%$.The polyunsaturated fatty acids percentages were 58.3, 61.2 and $31.3 \%$, respectively. In contrast, the mono unsaturated fatty acids percent was dramatically decreased to level ranging between 17.6 to $18.6 \%$ for the other irrigation methods. Therefore, the polyunsaturated fatty acids increased to levels ranging between 69.9 to $72.0 \%$ compared to the control sample which had $58.5 \%$. Generally, the decreases in the mono unsaturated fatty acid levels lead to increases in the polyunsaturated fatty acids. This relation result shows the effect of some irrigation methods in the oleic and linoleic acids biosynthesis. According to the obtained data, the oleic acid decreased with increased linoleic acid in the oil samples which were extracted from the seeds. Those were affected by the irrigation method as previously clarified. The total saturated fatty acids was not affected by different irrigation methods. The fatty acid profiles for the different oil samples were extracted from seeds Giza 102. Those were 
treated by the same irrigation methods presented in Table (9). Generally, no effect was observed between the treated samples and the control sample. The total saturated fatty acids mono unsaturated fatty acids ranged between 10.2 to $11.5 \%$ compared to the control sample which was 10.9 $\%$. Monounsaturated fatty acids ranged between 20.3 to $17.6 \%$ compared to the control sample which had was $19.5 \%$. At the same time, polyunsaturated fatty acids in control sample was $69.6 \%$ in the range with the other treated samples that ranged between 68.6 to $71.9 \%$.

Table (9): Fatty acid profile sunflower oil Saka 53.

\begin{tabular}{|c|c|c|c|c|c|c|c|c|c|}
\hline $\begin{array}{l}\text { Fatty } \\
\text { acid }\end{array}$ & $\begin{array}{c}\text { Ska53 } \\
\text { contro } \\
-1\end{array}$ & $\begin{array}{c}\text { Saka5 } \\
3 \\
100 \% \\
\text { SDI } \\
\end{array}$ & $\begin{array}{c}\text { Saka53 } \\
\text { 100\%SSD } \\
\text { I }\end{array}$ & $\begin{array}{c}\text { Saka53 } \\
80 \% \text { SD } \\
\text { I }\end{array}$ & $\begin{array}{c}\text { Saka53 } \\
80 \% \text { SSD } \\
\text { I }\end{array}$ & $\begin{array}{c}\text { Saka53 } \\
60 \% \text { SD } \\
\text { I }\end{array}$ & $\begin{array}{c}\text { Saka53 } \\
60 \% \text { SSD } \\
\text { I }\end{array}$ & $\begin{array}{c}\text { Saka53 } \\
50 \% \text { SD } \\
\text { I }\end{array}$ & $\begin{array}{c}\text { Saka53 } \\
50 \% \text { SSD } \\
\text { I }\end{array}$ \\
\hline C16:0 & 6.0 & 5.8 & 6.9 & 6.1 & 6.1 & 6.1 & 6.0 & 6.6 & 6.6 \\
\hline C16:1 & 0.1 & 0.1 & 0.3 & 0.2 & $\begin{array}{l}0.1 \\
\end{array}$ & 0.1 & 0.5 & 0.1 & 0.1 \\
\hline C17:0 & 0.0 & 0.1 & 0.2 & 0.1 & 0.0 & 0.0 & 0.2 & 0.1 & 0.1 \\
\hline C17:1 & 0.0 & 0.0 & 0.1 & 0.0 & 0.0 & 0.0 & 0.1 & 0.0 & 0.0 \\
\hline C18:0 & 3.6 & 3.4 & 3.8 & 3.7 & 3.7 & 3.7 & 2.7 & 3.7 & 3.8 \\
\hline C18:1 & 30.6 & 17.2 & 17.6 & 31.1 & 27.8 & 31.0 & 17.9 & 17.4 & $\mathbf{1 7 . 5}$ \\
\hline C18:2 & $\begin{array}{l}58.4 \\
\end{array}$ & 71.2 & 69.8 & 58.2 & 61.1 & $\begin{array}{l}57.8 \\
\end{array}$ & 71.9 & 70.9 & 70.8 \\
\hline C18:3 & 0.1 & 0.1 & 0.1 & 0.1 & 0.1 & 0.1 & 0.1 & 0.1 & 0.1 \\
\hline C20:0 & 0.3 & $\begin{array}{l}0.3 \\
\end{array}$ & $\begin{array}{l}0.3 \\
\end{array}$ & $\begin{array}{l}0.3 \\
\end{array}$ & 0.3 & $\begin{array}{l}0.3 \\
\end{array}$ & 0.2 & 0.3 & $\begin{array}{l}0.3 \\
\end{array}$ \\
\hline C20:1 & 0.2 & 0.2 & 0.2 & 0.1 & 0.2 & 0.2 & 0.2 & 0.1 & 0.2 \\
\hline C22:0 & 0.8 & 0.8 & 0.8 & 0.0 & 0.7 & 0.7 & $\begin{array}{l}0.3 \\
\end{array}$ & 0.6 & 0.7 \\
\hline TSFA & 10.7 & 10.4 & 11.9 & 10.1 & 10.7 & 10.7 & 9.4 & 11.3 & 11.4 \\
\hline $\begin{array}{c}\text { MUF } \\
\mathbf{A}\end{array}$ & 30.8 & 17.6 & 18.2 & 31.5 & 28.0 & 31.3 & 18.6 & 17.7 & 17.8 \\
\hline PUFA & 58.5 & 71.4 & 69.9 & 58.3 & 61.2 & 57.9 & 72.0 & 71.0 & 70.9 \\
\hline
\end{tabular}


J. Environ. Sci.

Institute of Environmental Studies and Research - Ain Shams University

Table (10): Fatty acids profile sunflower oil Giza102.

\begin{tabular}{|c|c|c|c|c|c|c|c|c|c|}
\hline $\begin{array}{l}\text { Fatty } \\
\text { acid }\end{array}$ & $\begin{array}{c}\text { Giza1 } \\
02 \\
\text { contro } \\
-1 \\
\end{array}$ & $\begin{array}{c}\text { Giza102100 } \\
\% \text { SDI }\end{array}$ & $\begin{array}{c}\text { Giza102 } \\
\text { 100\%SS } \\
\text { DI }\end{array}$ & $\begin{array}{c}\text { Giza10 } \\
2 \\
80 \% \mathrm{~S} \\
\text { DI } \\
\end{array}$ & $\begin{array}{c}\text { Giza102 } \\
\text { 80\%SS } \\
\text { DI }\end{array}$ & $\begin{array}{c}\text { Giza10 } \\
2 \\
60 \% \mathrm{~S} \\
\text { DI } \\
\end{array}$ & $\begin{array}{c}\text { Giza102 } \\
60 \% \text { SS } \\
\text { DI }\end{array}$ & $\begin{array}{c}\text { Giza10 } \\
2 \\
50 \% \mathrm{~S} \\
\text { DI }\end{array}$ & $\begin{array}{c}\text { Giza102 } \\
\text { 50\%SS } \\
\text { DI }\end{array}$ \\
\hline C16:0 & $\begin{array}{l}6.3 \\
\end{array}$ & 6.5 & 6.7 & $\begin{array}{l}5.8 \\
\end{array}$ & 6.2 & 6.3 & 6.6 & $\begin{array}{l}6.3 \\
\end{array}$ & 6.3 \\
\hline C16:1 & 0.1 & 0.1 & 0.1 & 0.1 & 0.1 & 0.1 & 0.2 & 0.1 & 0.1 \\
\hline C17:0 & 0.0 & 0.0 & 0.1 & 0.0 & 0.0 & 0.0 & 0.0 & 0.0 & 0.0 \\
\hline C17:1 & 0.0 & 0.0 & 0.0 & 0.0 & 0.0 & 0.0 & $\begin{array}{c}0.0 \\
\end{array}$ & 0.0 & 0.0 \\
\hline C18:0 & 3.7 & 3.6 & \begin{tabular}{|l|l|}
3.7 \\
\end{tabular} & \begin{tabular}{|l|}
3.8 \\
\end{tabular} & 3.7 & 3.6 & 3.6 & 3.7 & 3.7 \\
\hline C18:1 & 19.2 & 17.3 & 17.5 & 17.6 & 18.9 & 20.0 & 17.3 & 17.5 & 17.4 \\
\hline C18:2 & 69.5 & 71.1 & 70.6 & 71.8 & 70.0 & 68.5 & 71.0 & 70.9 & 71.1 \\
\hline C18:3 & 0.1 & 0.1 & 0.1 & 0.1 & 0.1 & 0.1 & 0.1 & 0.1 & 0.1 \\
\hline C20:0 & 0.2 & 0.3 & 0.3 & 0.3 & 0.3 & 0.2 & 0.3 & 0.4 & 0.3 \\
\hline C20:1 & 0.2 & 0.2 & 0.2 & 0.2 & 0.2 & 0.2 & 0.2 & 0.2 & 0.2 \\
\hline C22:0 & 0.7 & 0.8 & 0.7 & 0.4 & 0.5 & 0.9 & 0.8 & 0.8 & 0.8 \\
\hline TSFA & 10.9 & 11.1 & 11.5 & 10.2 & $\begin{array}{ll}10.7 \\
\end{array}$ & 11.1 & 11.3 & 11.2 & 11.1 \\
\hline $\begin{array}{c}\text { MUF } \\
\text { A }\end{array}$ & 19.5 & 17.7 & 17.8 & 17.8 & 19.2 & 20.3 & 17.6 & 17.8 & 17.7 \\
\hline $\begin{array}{c}\text { PUF } \\
\text { A }\end{array}$ & 69.6 & 71.2 & 70.7 & 71.9 & 70.1 & 68.6 & 71.1 & 71.0 & 71.2 \\
\hline
\end{tabular}

\section{CONCLUSION}

Subsurface drip irrigation is more compatible for irrigating sunflower than surface drip irrigation, as it gave the highest growth parameters, seed yield $(\mathrm{kg} / \mathrm{fed})$ and oil\% in seed for all experiments. WUE of seed yield was greater in (SSDI) than (SDI). Also, WUE of oil yield was greater in (SSDI) than (SDI). The treatment of Saka53 when applying water at $80 \%$ of the ETo (SSDI) had $41.3 \%$ oil yield .At the same time, the oil quality was improved by increasing the Poly unsaturated fatty acids from 58.54 in the content sample to $61.2 \%$ in the treated seed. On the other hand variety Giza102 at $100 \%$ of the ETo (SSDI) had significantly $(\mathrm{p}<0.05)$. The highest oil yield was $43.4 \%$ with 70.79 polyunsaturated fatty acid. AU the physico-chemical characteristics of the extracted oil were not affected by the different irrigation treatments. The Acid Value (AV) mg KOH/g oil, Peroxide value (PV) 
meq. $\mathrm{O}_{2} / \mathrm{kg}$ oil, Anisidine value $\mathrm{AnV}$ meq. $/ \mathrm{kg}$ oil, TOTOX and refractive indexes at $25^{\circ} \mathrm{C}$ were lower than these in the standards. Significant differences between the means do not express the good or poor quality of the oil. However, all the produced oil had chemical good quality. That means, no effect of the irrigation methods on the chemical sunflower oil quality extracted from two hybrid seeds.

According to the obtained result, there are two environmental benefits:

1- Saving the irrigation water during cultivation of sunflower crop.

2 - The fatty acid profile of the sunflower oil is improved with more

polyunsaturated fatty acid. The consumer will have healthy benefit with that oil.

\section{REFERENCES}

A.O.A.C. (2000) .Seed oil percentage was determined using soxholets apparatus according to A.O.A.C(2000).

A.O.A.C. (2000). Oils and Fat. In: Official methods of analysis of the Association of Official Analytical Chemists (AOAC), 17th edn. AOAC I. Gaithersburg, MD, USA: 1-69.

Abitogun, A.S and Oshodi, A.A. (2010). Effects of degumming and bleaching on physicochemical properties of crude sunflower oilseeds. J. Chem .Soci of Nigeria, 35: 57-61.

Allen, R.G., Pereira, L. S., Raes, D., Smith, M.; (1998): Crop Evapotranspiration - Guidelines for Computing Crop Water Requirements. FAO Irrigation and Drainage paper 56. Food and Agriculture Organization, Rome.

Allman-farinelli, M.A., Gomes, K., Favaloro, E.J., Petocz, P., (2005). A diet rich in higholeic-acid sunflower oil favorably alters low-density lipoprotein cholesterol, triglycerides, and factor VII coagulant activity. J. Am. Diet. Assoc. 105: 1071- 1079. 
AOAC, (2000). Official Methods of Analysis Assoc of Official Analytical Chemists, 16th ed., Virginia, USA.

AOCS, (1998). Official Methods of Analysis. American Oil Chemists' Society. Method Cd 18-90. Champaign, Ill, Wash DC.

ASAE. (1994). ASAE Standards. Joseph, MI. S248.3: 437-444.

Black, C.A., Evans, Fisher, R.F. and D. Binkley (2000). Ecology and management of forest soils. John Wiley and Sons Ltd., N. Y.: 512.

Cox, W. J. and Jolliff, G.D. (1986). Growth and yield of sunflower and soybean under soil water deficits. Agron. J. 78:226-30.

Davideseu, D., Crisan, I., Davidescu, V. and Borza, J., (1977). Relationship between environmental conditions and oil content in sunflower and soyabean. In: Proc. Colloq. Int. Potash Inst., No. 13, Fertilizer Use and Production of Carbohydrates and Lipids, York, England. International Potash Institute, Bern: 311-327.

Day, p. R. (1965). Pa rticle fractionat ion and part icle-s izeanalys is. In C. A. Black, ed. Me thods of soi I analys is. Agronomy 9:545- 567.

De Abreu, D.A.P.; Losada, P.P.; Maroto, J.; Cruz, J.M.(2010) Evaluation of the effectiveness of a new active packaging film containing natural antioxidants (from barley husks) that retard lipid damage in frozen Atlantic salmon (Salmo salar L.). Food Res. Int. 43: 1277-1282.

El-Hendawy, S.E., El-Lattief, E.A., Ahmed, A.S., Schmidhalter, U., 2008. Irrigation rate and plant density effects on yield and water use efficiency of drip irrigated corn. Agric. Water Manage. 95: 836844.

FAO,( 2011). http://www.fao.org/nr/water/cropinfo_sunflower.html

Farhoosh, R., Niazmand, R., Rezaei, M., Sarabi, M., (2008). Kinetic parameter determination of vegetable oil oxidation under Rancimat test conditions. Eur. J. of Lipid Sci. and Tec. 110: 587592.

Gimenez, C. and Fereres , E.(1986). Genetic variability in sunflower cultivars under drought. $11 *$ Growth and water relations. Aust.J.Agric.Res 37: 583-597.

Gupta, M.K., (2003). Fundamental quality control in vegetable oil refining. Oil Mill Gazet. 108: 6-9. 
Isrealsen,O.W and V.E.Hansen (1962). Irrigation Principles and Practices. 447 pp., Third ED., JohnWiley and Sons,Newyork.

Jackson, M.L. (1978). "Soil Chemical Analysis", Englewood Cliffs, New Jersey, Pretice-Hall, Inc.

Kandil, A.A.(2000). Sunflower head development as affected by irrigation intervals. Annals of Agr Sci.,Mostohor, 22: 3-13.

Keller J, Karmeli D (1975). Trickle Irrigation Design. Rain Bird Sprinkler Manufacturing Corporation Glendora, California, U.S.A, 1-5, 17-18: 46-49.

Lamas n, Diana D.T., and Raab,D. (2016). Effect of degumming process on physicochemical properties of sunflower oil. Biocatalysis and Ag Biotec $6: 138-143$.

Lorite I.J., Mateos L., Orgaz F. and Fereres E., (2007). Assessing deficit irrigation strategies at the level of an irrigation district. In: Agr Water Management, 91: 51-60.

Murriel, J.L., (1975). Yield of sunflower in field plots in response to various watering regimes and to irrigation during critical phases of growth. In: Proceedings of the Sixth International Sunflower Con. Int. Sunflower Association, Romania,: 577-582.

Palanisami K, Senthilvel S, Ramesh T (2009). Water productivity at different scales under canal, tank and well irrigation systems International Water Management Institute.

Razi, H., M.T. Assad (1999). Comparison of selection criteria in normal and limited irrigation in sunflower. Euphytica105: 83-90.

Rinaldi, M., (2001). Application of EPIC model for irrigation scheduling of sunflower in Southern Italy. Agric. Water Manag. 49,: 185-196.

Shahidi, F., Wanasundara, U.N., (2002). Methods for measuring oxidative rancidity in fats and oils. In: Akoh, C.C., Min, D.B. (Eds.), Food Lipids-chemistry, Nutrition, and Biote, second ed. Marcel Dekker, Inc., N. Y.: 465-487.

Shinde, S.H., Dhonde, P.W. \& Pawar, A.D. (1987): Effects of depth and frequency of irrigation on yield of sunflower. J. of Maharashtra Agric. Univ. 12: 104-105.

Sinha Indu, G.S. Buttar, A.S. Brar (2017). Drip irrigation and fertigation improve economics, water and energy productivity of spring sunflower (Helianthus annuus L.) in Indian Punjab Agric. W. Man. 185: 58-64. 
Unger, P.W. and Thompson, T.E., (1982). Planting date effecs on sunflower head and seed development. Agron. J., 74: 389-395.

Zhang, Y.; Yang, L.; Zu, Y.; Chen, X.; Wang, F.; Liu, F. (2010). Oxidative stability of sunflower oil by carnosic acid compared with synthetic antioxidants during accelerated storage. Food Chem. $118,: 656-662$

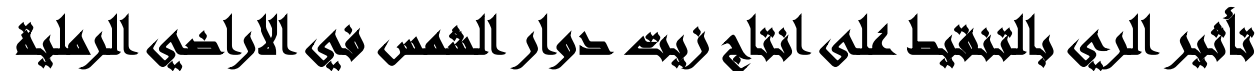

[

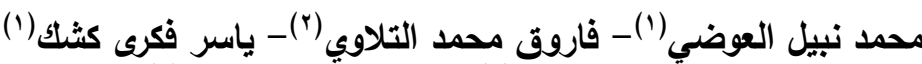

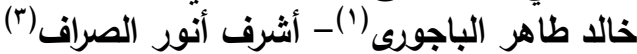

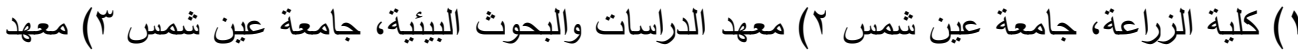

بحوث الهندسة الزراعية والري مركز البحوث الزئة الزية

\section{المستحلي}

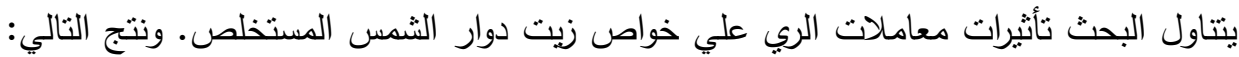

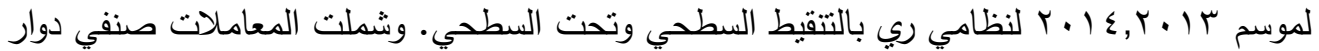

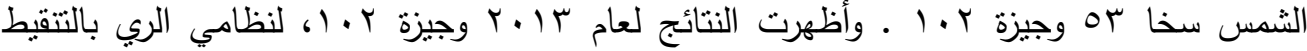

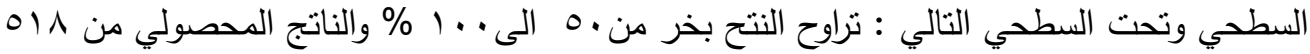

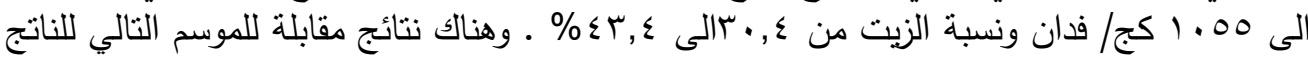

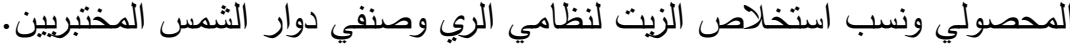
وفى الخلاصة، فان معاملات الري لها تأثثرات كبيرة على انتاج الزيت ونوعيته 